\title{
Effect of Solar Heater Boxes on Seed Quality of Adzuki Bean (Vigna angularis)
}

\author{
${ }^{1}$ Ragaa M. E. Elhadaa, ${ }^{2}$ Rita Muhamad Awang, ${ }^{2}$ Dzolkhifli Omar, \\ ${ }^{3}$ Uma Rani Sinniah and, ${ }^{4}$ Ionel Vaieriu Grozescu \\ ${ }^{I}$ Department of Plant Protection, Faculty of Agricultural Studies,Sudan Univ.of Science and Technology. \\ ${ }^{2}$ Department of Plant Protection, Faculty of Agriculture, University Putra Malaysia, 43400 UPM, Serdang. \\ 3Department of Crop Science, Faculty of Agriculture, University Putra Malaysia, 43400 UPM, Serdang. \\ ${ }^{4}$ Faculty of Engineering, SEG: University College, Kota damansara
}

\begin{abstract}
The effect of solar heater boxes on germination, moisture content and seedling characteristics of adzuki bean beans seeds V. angularis was determined using cardboard and plywood solar heater boxes. Results showed that, exposure to cardboard and plywood solar heater boxes did not show enormous effect on germination characters for adzuki bean seeds. In addition, experiment in oven was done for more verification. Exposure to temperatures of 40,50,60, and $70^{\circ} \mathrm{C}$ did not affect germination of adzuki bean seeds.
\end{abstract}

Key words: Vigna angularis, solar heater boxes, constant temperatures, seed quality, adzuki bean

\section{Introduction}

Legumes are excellent vegetable sources of proteins and oils. Moreover they are considered as organic fertilizers because of their ability to fix atmospheric nitrogen (Gonzales et al., 2005). Legumes contribute 33\% of the dietary protein nitrogen $(\mathrm{N})$ needed for humans and they are also rich in fiber and energy (Vance et al., 2000; Graham and Vance, 2003). In addition, forage legumes have been the base for dairy and meat production for centuries (Russelle, 2001). Many of these species produce multiple edible products, which provide subsistence farmers with a food supply throughout the growing season as well as dry seeds that are easy to store and transport (Fery, 2002). Seeds are also known to be an important input for establishment of a cropping system. Seed vigor and viability are essential components influencing seedling establishment, crop growth, and productivity. Any factor that negatively affects vigor and viability during seed development will have adverse consequences for crop planting (Welch, 1999). Unfavorable storage conditions can result in loss in germination at a rapid rate. Unfavorable storage conditions can also lead to insect infestations which result in contamination and loss of quality in the crop. Overall, the changes in the beans due to unsatisfactory storage conditions lead to a reduction in their commercial value (Hill, 1975; Yousif et al., 2002). Seed moisture content, temperature and relative humidity of the storage are considered as essential parameters for good bean preservation (Yousif, et al., 2002). Infested seeds are not fit for consumption and especially for planting. Therefore, maintenance of seed quality for the following years is one of the problems that face farmers (Mbaiguinam et al., 2006). In previous study, it was found that cardboard and plywood had suitable thermal properties to be used in solar heater boxes in addition to their low cost. The use of such methods is promising for minimizing pests, but its effect on seed quality as planting materials is not known. Consequently, the present experiment was designed to evaluate the effect of temperatures in these two solar heater boxes on germination, moisture content and seedling characteristics of adzuki bean ( $V$. angularis).

\section{Materials And Methods}

\subsection{Effect of solar heater box treatments on seed quality of adzuki beans ( $V$. angularis)}

Effect of solar heater boxes on quality of adzuki bean seeds was determined. One kilogram of disinfested seeds were placed in Perspex tray in the middle of the cardboard and plywood solar heater boxes and exposed to the sun for $15,30,45,60,75,90$, and 120 minutes, and untreated seeds were included as control.

\subsubsection{Moisture content}

After each treatment period, the seeds were mixed randomly and $20 \mathrm{gm}$ seeds were sampled from each treatment and placed in $9 \mathrm{~cm}$ aluminum Petri dishes in an oven $\left(103 \mathrm{C}^{\circ}\right)$ (Protech-Model FAC-50D) for 24 hours. Thereafter, seeds were placed in a desiccator for one hour for cooling, before recording the dry weight. Moisture content percent was calculated for each treatment according to the method of ISTA (2007).

\subsubsection{Germination percentage}

After each treatment period, the seeds were mixed randomly and thirty seeds from each treatment were spread on moistened filter paper in $15 \mathrm{~cm}$ glass Petri dishes and kept moist for one week. The experiment was conducted in a growth chamber. Number of germinated seeds was counted daily and percent germination was calculated. 


\subsubsection{Germination rate}

Rate of germination was determined using the formula by Karaguzel (2004)

Germination rate $=\underline{\text { No of normal seedlings }}$

+ . No of normal seedlings

Days of first count Days of final count

\subsubsection{Seedling abnormality}

The germinated seeds were examined for normal and abnormal seedlings and were classified after one week. The abnormal seedlings were counted, and the percent of abnormality was calculated to determine the effect of solar heater boxes on seedling abnormality.

\subsubsection{Root and shoot length}

$=$ To evaluate the effect of constant heat on seedling germination of adzuki bean, root and shoot lengths of germinated seedling were measured.

\section{Data Analysis}

All experiments were conducted in a completely randomized design (CRD) with three replications. For the experiment on solar heater boxes, treatments were analyzed as a factorial (of two-factors). Percent seed abnormality data were transformed by Arcsine transformation and analyzed as a general linear model (GLM) to account for the missing values. Normal data was used for the other parameters and analysis of variance (ANOVA) procedure was used to analyze the data. The differences between means were determined using Duncan's multiple range test. Statistical Analysis Software (SAS) was used to analyze all data.

\section{Results And Discussion}

\subsection{Effect of solar heater box treatments on seed quality of adzuki beans ( $V$. angularis)}

\subsubsection{Moisture content}

The effect of cardboard and plywood solar heater boxes on moisture content of adzuki bean seeds upon exposure for different durations are presented in Figure 1. The moisture content of seeds prior to exposure was $13.6 \%$. Exposure to solar heat for 15 minutes caused a $1.1 \%$ loss in moisture content for both solar heater boxes. When exposure was extended to 30 minutes the moisture loss was 1.2 and $1.1 \%$ for plywood and cardboard solar heater boxes, respectively. A reduction of $1.5 \%$ was recorded when seeds were exposed to solar heat for 45 minutes for both solar heater boxes. When the exposure time was extended to 60 minutes the loss in moisture content was 2.0 and $2.1 \%$ for seeds treated in plywood and cardboard boxes, respectively. The effect of exposure time was highly significant $(\mathrm{p}<0.0001)$. Moreover, the interaction effect of the two factors, materials and exposure times, on moisture content was significant $(\mathrm{p}=0.01)$.

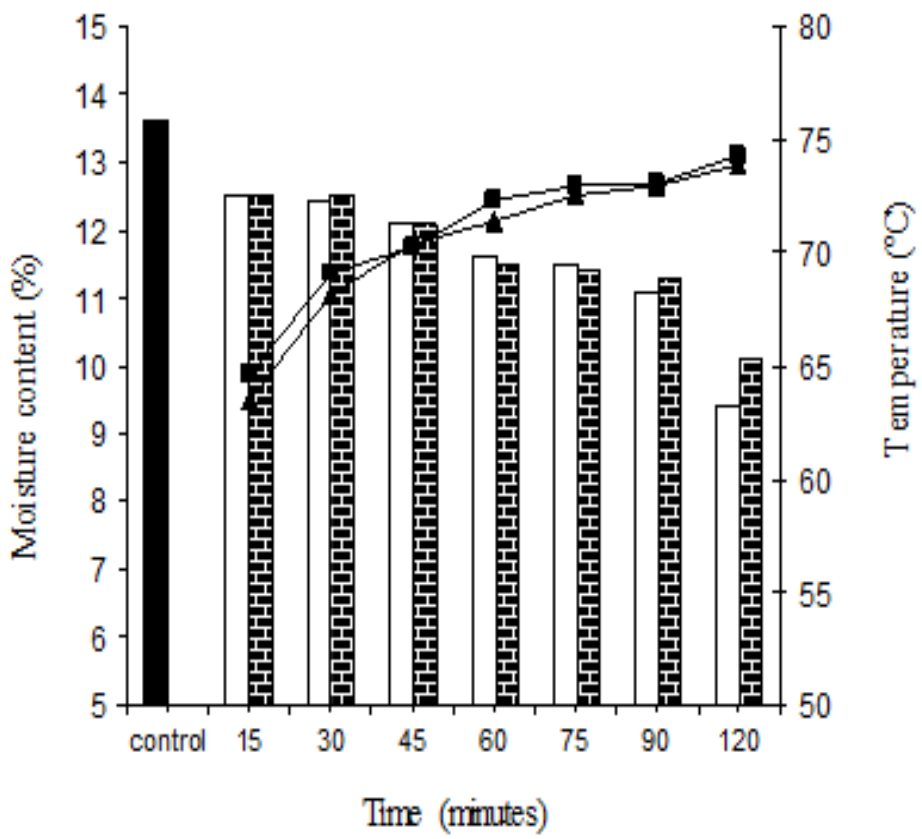

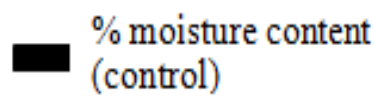

$\square \%$ moisture content (plywood)

\% moisture content (cardboard)

- temperature (plywood)

- -temperature (cardboard)

Figure 1.Changes in adzuki bean seed moisture content due to solar heater box treatments for different durations 
Solar heater box treatments for up to 75 minutes raised the temperature between seed temperature to $72{ }^{\circ} \mathrm{C}$ in both solar heater boxes. The loss in seed moisture content at this exposure period was 2.1 and $2.2 \%$ for seeds treated in plywood and cardboard solar heater boxes, respectively. Seeds exposed to 90 minutes, resulted in moisture content loss of 2.5 and $2.3 \%$ for the respective boxes. Mekasha et al (2006) reported a moisture loss of 2.3 and $2.8 \%$ in adzuki bean seed treated with solar heat for 75 and 90 minutes, respectively with an initial moisture content of $13.5 \%$. The different results were due to the differences in temperatures obtained by the solar heater boxes in the two experiments. The loss was higher in Mekasha's experiment probably because of the higher temperature trapped in metal solar heater boxes compared to temperatures trapped by cardboard and plywood solar heater boxes in this study.

The results showed that moisture content was significantly $(\mathrm{p}<0.0001)$ influenced by both solar heater box treatments. It was observed that the minimum moisture content for seeds treated in cardboard solar heater boxes was $10.1 \%$ for a120 minute duration of exposure, where the temperature reached $73.9{ }^{\circ} \mathrm{C}$. In plywood solar heater boxes, temperatures which increased to $74.3{ }^{\circ} \mathrm{C}$ with exposure time of 120 minutes decreased moisture content to $9.4 \%$. The results showed that the exposure time increased temperature in seeds, but did not affect moisture content very much. Burg (2004) recommended seed moisture content for bean storage at between 9.5 and $11.5 \%$. Therefore, in this study the decrease below the level of $13.6 \%$ suggests the beneficial effects of solar heater boxes in seed storage. According to Ntoukam et al (1997) sun-treated cowpeas averaged 13-15\% seed moisture, and the solar process further reduced this moisture level, This effect on seed moisture level is considered as an advantage of solar heating for seed preservation. The use of cardboard solar heater boxes is therefore recommended as it did not reduce seed moisture content to less than $10 \%$.

\subsubsection{Germination percentage}

The effects of cardboard and plywood solar heater boxes on percent seed germination of adzuki bean are presented in Figure 2. Exposure to the sun for 15 minutes raised temperatures to 63.5 and $64.6{ }^{\circ} \mathrm{C}$ in cardboard and plywood solar heater boxes, respectively; but this did not affect seed viability as a high percentage of germination similar to untreated seeds were obtained. In addition, an extended exposure time of 30 minutes increased temperatures to 68.2 and $69.1{ }^{\circ} \mathrm{C}$, resulted in germination percentages of 91.1 and $94.5 \%$ in seeds from cardboard and plywood solar heater boxes, respectively. This response could also be due to the fact that slight heating of seeds for short exposure times might initiate germination of the seeds which otherwise would have not germinated (Mekasha, 2004).

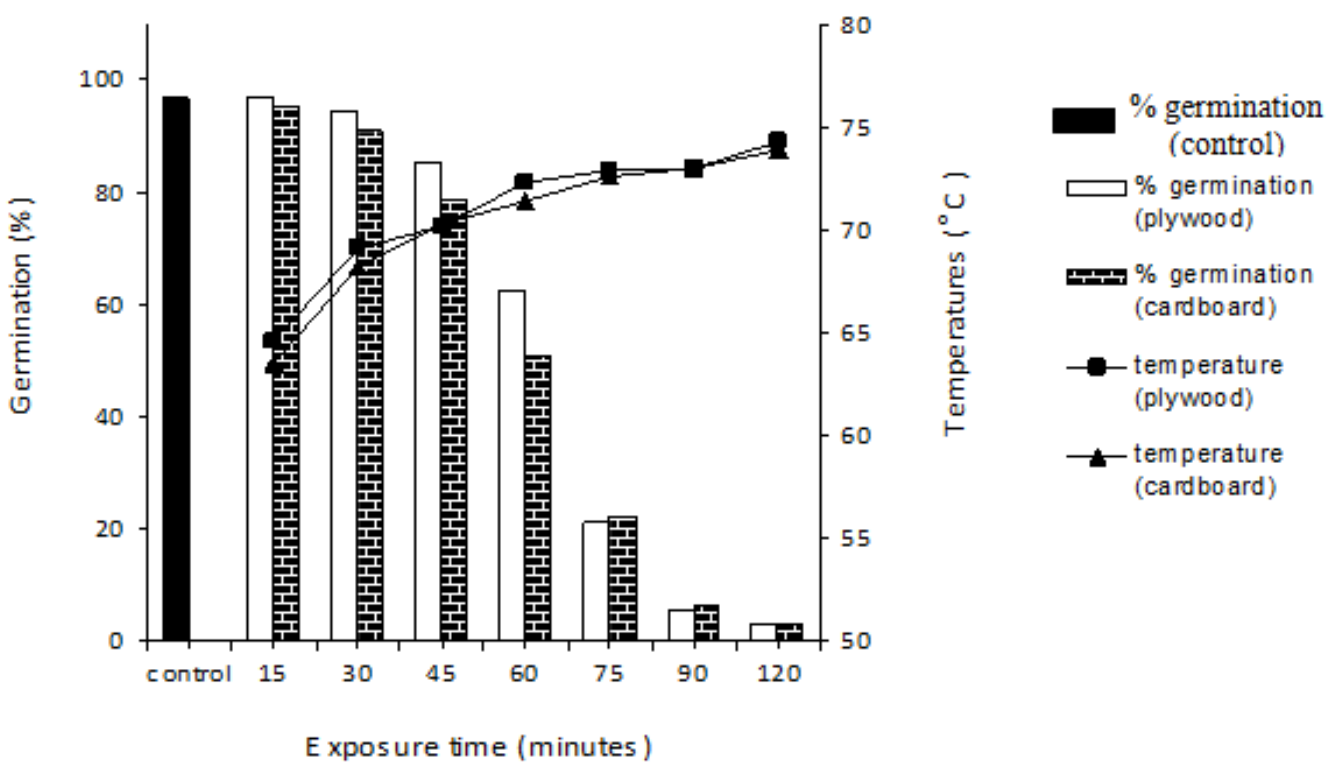

Figure 2. Effect of solar heater boxes on seed germination of adzuki bean

Exposure to heat for 45 minutes decreased germination to 85.6 and $78.9 \%$ in seeds treated in plywood and cardboard solar heater boxes, respectively, compared to $96.7 \%$ for untreated seeds. Adzuki bean seeds exposed to solar heat for 60 minutes at 72.3 and $71.4{ }^{\circ} \mathrm{C}$ in plywood and cardboard solar heater boxes, respectively, showed a significant influence on seed viability. In contrast, Ntoukam et al (1997) reported that, solar heating up to $85{ }^{\circ} \mathrm{C}$ did not affect seedling viability of cowpea seeds. In a study by Chauhan and Ghaffar (2002) also showed that solarization in polyethylene bags resulting in high temperatures had no adverse effects on germination of pigeon pea seeds. This difference may be attributed to the higher sensitivity of adzuki bean 
seeds to high temperatures.The effect of exposure time on germination was highly significant $(p<0.0001)$.The effect of solar heater box materials on germination was also significant. In addition, the interaction between the two factors on their effect on germination was also significant.Exposure to heat for 75, 90 and 120 minutes raised the temperatures to $70{ }^{\circ} \mathrm{C}$ in both solar heater boxes. At these exposure times, the high temperatures in both solar heater boxes significantly affect germination of seeds. These results were similar to the findings of Mekasha (2004) who reported that exposure to solar heat for 75 and 90 minutes significantly affected seed viability of adzuki bean. In contrast, Lale and Ajayi (2001) found that solarization in metal tins for 7 hours with temperatures of up to $57^{\circ} \mathrm{C}$ had no significant adverse effect on germinability of bambara groundnut seeds.

\subsubsection{Germination rate}

Effect of cardboard and plywood solar heater boxes on rate of germination of adzuki bean seeds is depicted in Figure 3. Exposure to heat for 15, 30 and 45 minutes resulted in high germination rates. The germination rate at 15 minutes of exposure was 13.5 and $13.9 \%$, and at 30 minutes it was 13.2 and $13.8 \%$ for seeds treated in cardboard and plywood solar heater boxes respectively, compared to $14.3 \%$ in the control. When exposure to solar heat was extended for one hour, the temperatures increased to 71.4 and $72.3{ }^{\circ} \mathrm{C}$ in cardboard and plywood solar heater boxes, respectively, and the germination rate decreased to 5.3 and $6.9 \%$.

Adverse effects on germination rate occurred when the exposure time was extended to 75 and 90 minutes. The germination rates were $91.1 \%$ and $86.7 \%$ lower than untreated control in plywood and cardboard solar heater boxes, respectively. The decrease in germination rate of adzuki bean after 75 and 90 minutes exposure is due to the increase in temperatures of up to $72{ }^{\circ} \mathrm{C}$ with long durations of exposure, as the effect of temperature is a function of exposure time. Hartman et al (2002) reported that at high temperatures, germination rates are faster but above an optimum level where the rate is most rapid, a decline occurs as temperature approaches a lethal limit where the seed is injured. It was observed that germination rate decreased with increase in temperature. From the literature it was known that temperature is one of the major factors that influence seed viability.

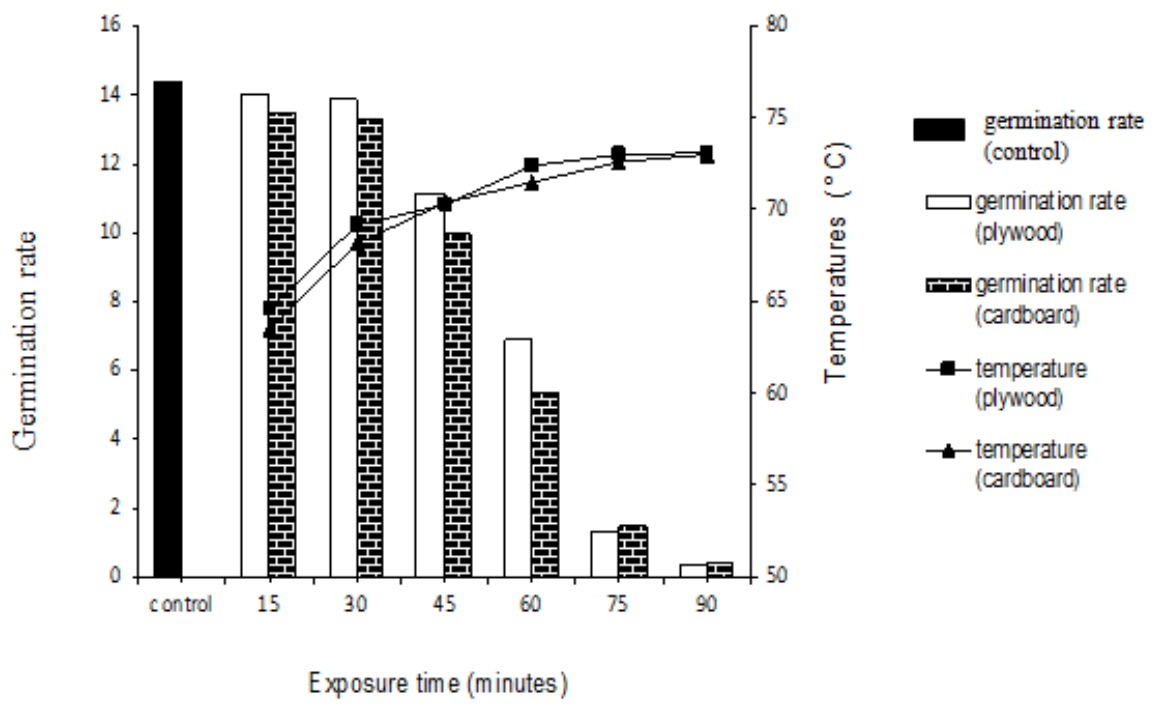

Figure 3. Effect of solar heater boxes on germination rate of adzuki beans

\subsubsection{Seedling abnormality}

The effect of plywood and cardboard solar heater boxes on seedling abnormality of adzuki bean is presented in Figure 4. The results showed that the abnormality increased with increase in exposure time. Exposure to heat for 15 and 30 minutes resulted in $100 \%$ seed normality similar to the untreated check for both solar heater boxes. When the exposure time was extended to 45 and 60 minutes, the temperatures increased to 70.3 and $70.2{ }^{\circ} \mathrm{C}$ in cardboard and plywood solar heater boxes, respectively; but seedlings were normal and not significantly different from the untreated seeds.A significant impact on seedling abnormality occurred at 75 minutes of exposure and higher. When seeds were exposed to solar heater boxes for 120 minutes $(2 \mathrm{~h})$ the abnormality was raised to $100 \%$. The effect of exposure time on seed abnormality was highly significant $(\rho<0.0001)$. However, the effect of solar heater box materials was not significant.

The interaction between the two factors, materials and exposure time, was not significant. Each factor was independent on its effects on seed abnormality. 


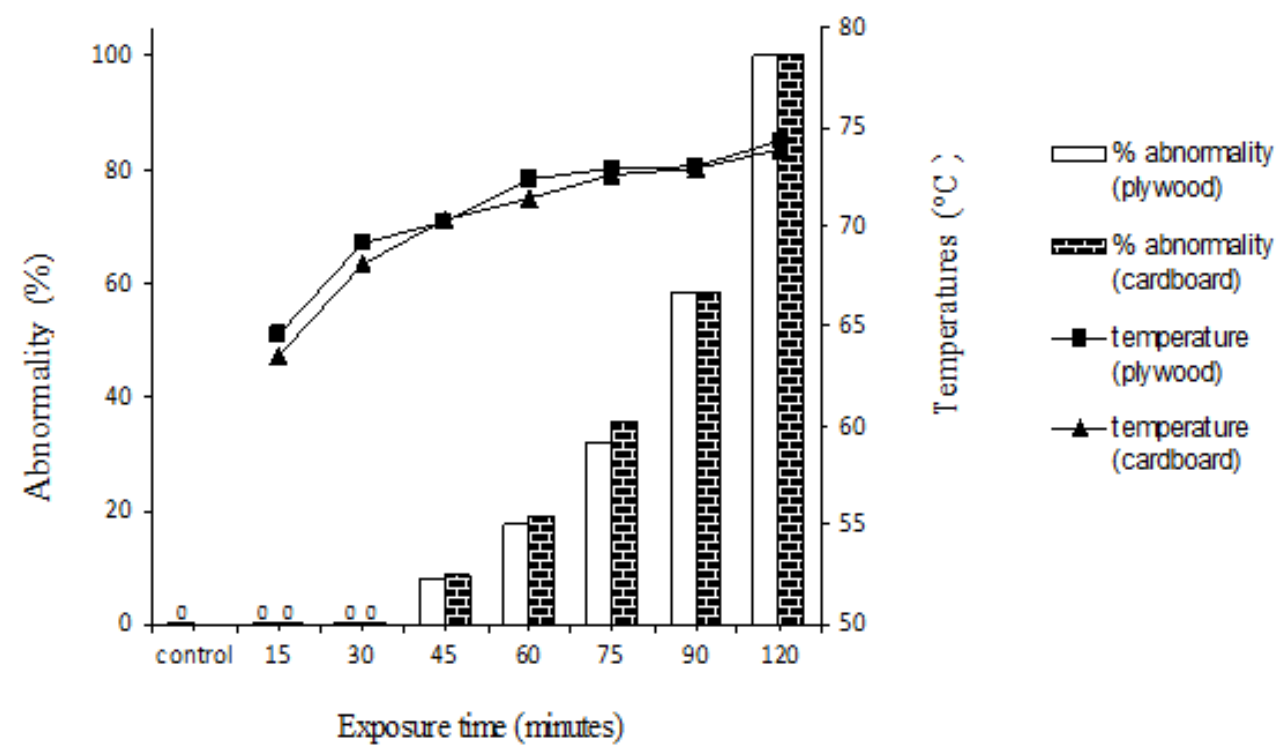

Figure 4. Effect of solar heater boxes on seed abnormality of adzuki bean

The results showed that cardboard and plywood solar heater boxes had no adverse impact on seed normality when exposure time of solar heat was extended up to one hour. In this study the significant abnormality at 75 minutes of exposure and higher was due to the effect of long exposure times at high temperatures on cell division and expansion of seedling structure. According to Khanna (2008), the time of cell expansion varied greatly with temperature. Changes in temperature lead to declining cell division rates and expansion. When cells stop dividing, they stop usually at a point late in the phase known as restriction point.

\subsubsection{Root and shoot length}

The effect of cardboard and plywood solar heater boxes on root lengths of adzuki bean seedlings are presented in Figure 5. When seeds were exposed to solar heat for 15 and 30 minutes the root length of seeds treated in both solar heater boxes exceeded that of untreated seeds. Exposure to cardboard solar heater boxes for 15,30 and 45 minutes increased temperatures to $63.5,68.1,70.3^{\circ} \mathrm{C}$, respectively and this resulted in root lengths higher than in the untreated control. Seeds treated in plywood solar heater boxes for 15, 30, and 45 minutes had root lengths of 3.9, 3.6, and $3.1 \mathrm{~cm}$ which corresponded with temperatures of $64.6,69.1$, and $70.2{ }^{\circ} \mathrm{C}$, respectively. These results were not significantly different from the untreated control. However, exposure for up to one hour in both solar heater boxes showed significant effects on root lengths of adzuki bean.

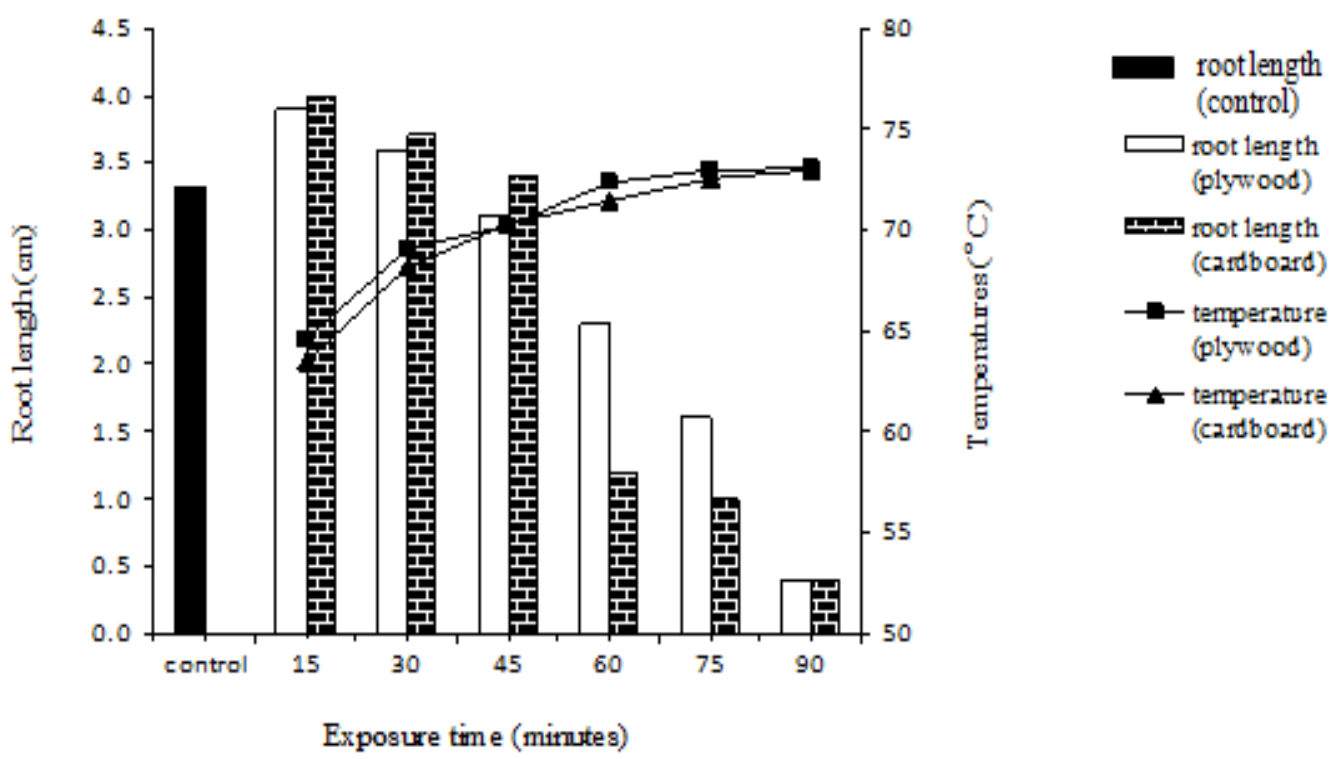

Figure 5. Effect of solar heater boxes on root length of adzuki beans 
The effect of exposure time on root length of adzuki bean was highly significant $(\mathrm{p}<0.0001)$. Moreover, the effect of solar heater box materials was also significant. The interaction effect of the two factors on root length was significant.Effects of cardboard and plywood solar heater boxes on shoot length of adzuki bean seedlings are presented in Figure 6. It was clear that, exposure to heat for 15, 30 and 45 minutes did not significantly affect shoot length for both solar heater boxes.Exposure to solar heat for 15, 30, and 45 minutes of exposure increased temperatures inside cardboard solar heater boxes to more than $63{ }^{\circ} \mathrm{C}$ and resulted in shoot lengths that were not significantly different compared to shoot length in the control. Similar results were obtained in plywood solar heater boxes when seeds were exposed for 15, 30, 45, and 60 minutes of exposure with temperatures above $64{ }^{\circ} \mathrm{C}$. The slight differences in shoot lengths between the two solar heater boxes was due to the slight differences in temperatures generated by the two solar heater boxes.

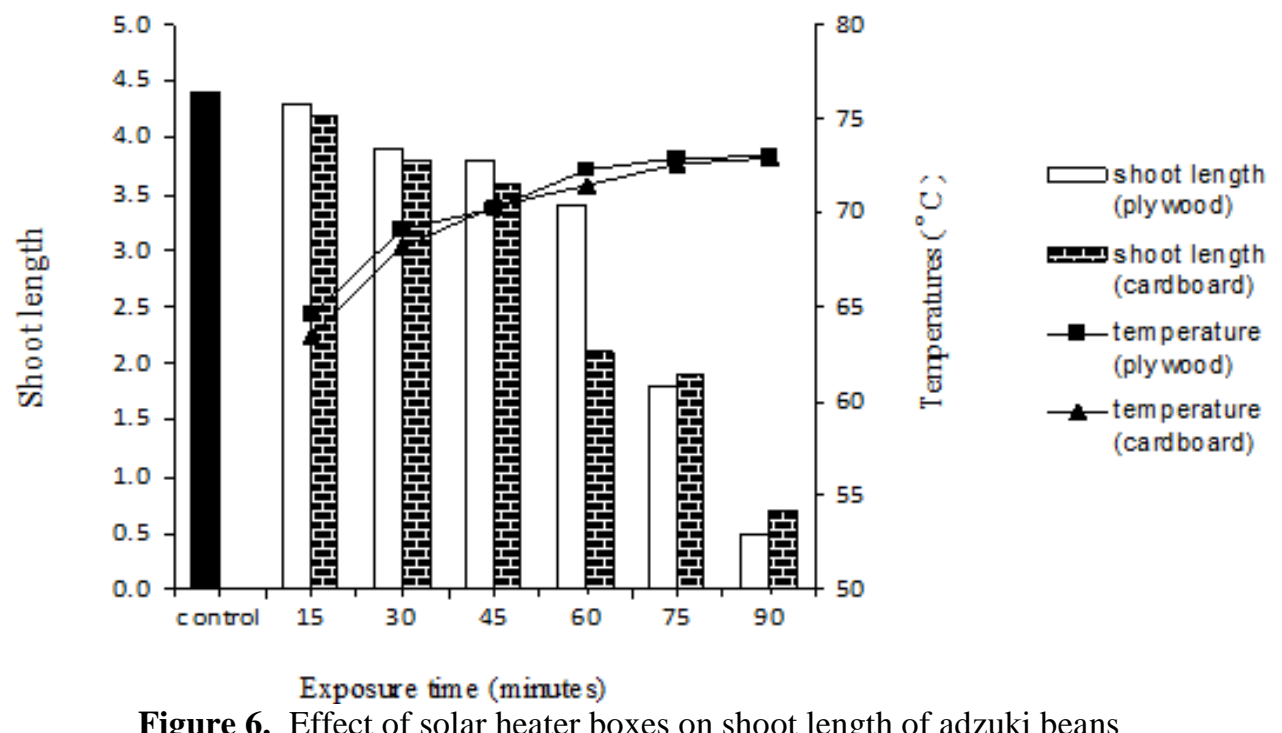

The effect of exposure time on shoot length was highly significant $(\mathrm{p}<0.0001)$. The effect of solar heater boxes was also significant. In addition, the interaction effect of two factors on shoot length was also significant. Shoot lengths were significantly affected when seeds were exposed to heat for one hour and above in the cardboard solar heater boxes. In plywood solar heater boxes however, significant effects on shoot lengths occurred when exposure was extended to 75 and 90 minutes. This was due to the differences in thermal diffusivity between the two solar heater boxes. Thermal diffusivity for cardboard is higher than that for plywood. This means that the spread of heat inside cardboard heater boxes is diffused faster than that inside plywood heater boxes where the heat needed more time to reach the seeds.

The greater extension in root and shoot lengths compared to the untreated seeds is due to the positive effect of temperature on cell division. Root growth is a function of cell elongation and cell division. According to Creber et al (1993), positive relationships exist between temperature increments and the duration of cell cycles in root development. Tardieu and Granier (2000) observed that an increase in temperature markedly increased cell division rate in epidermis and mesophyll, but did not affect the spatial patterns.

\subsection{Effect of constant heat on seed quality of adzuki bean $V$. angularis 4.2.1 Effect of constant heat at $40{ }^{\circ} \mathrm{C}$ on seed quality of adzuki been}

The influence of heat treatment at $40{ }^{\circ} \mathrm{C}$ on moisture content, germination percentage, root and shoot length of adzuki bean seeds are presented in Table 1 . The percentage moisture content achieved with heat treatment at $40{ }^{\circ} \mathrm{C}$ was significantly $(\mathrm{p}<0.0001)$ lower than that in untreated seeds for all exposure durations. Percentage of moisture contents achieved with exposure to temperature at $40{ }^{\circ} \mathrm{C}$ for durations of 10 to 60 minutes were not significantly different. However, when exposure time was extended to 70 minutes, the moisture content was decreased significantly compared to moisture content achieved with other durations. This difference was due to the long exposure time of 70 minutes compared to other durations.

It can be observed that although the temperature of $40{ }^{\circ} \mathrm{C}$ affected moisture content, however, it did not decrease moisture content to less than acceptable levels recommended for safe seed storage. Burg (2004) recommended that the moisture content for bean storage is between 9.5 and $11.5 \%$. The decrease in moisture content is one of the advantages of heat treatment for seed preservation. 
Table 1. Effect of constant heat at $40{ }^{\circ} \mathrm{C}$ on germination of adzuki bean results showed that exposure to heat at

\begin{tabular}{|c|c|c|c|c|}
\hline \multirow{2}{*}{$\begin{array}{c}\text { Exposure time } \\
\text { (minutes) }\end{array}$} & \multicolumn{3}{|c|}{ Temperatures $\mathbf{( 4 0} \mathbf{C})$} \\
\cline { 2 - 5 } & $\begin{array}{c}\text { Moisture content } \\
(\%)\end{array}$ & $\begin{array}{c}\text { Germination } \\
(\%)\end{array}$ & $\begin{array}{c}\text { Root length } \\
(\mathbf{c m})\end{array}$ & $\begin{array}{c}\text { Shoot length } \\
(\mathbf{c m})\end{array}$ \\
\hline Control & $13.6^{\mathrm{a}}$ & $96.7^{\mathrm{ab}}$ & $3.3^{\mathrm{d}}$ & $4.4^{\mathrm{a}}$ \\
\hline 10 & $12.0^{\mathrm{b}}$ & $99.9^{\mathrm{a}}$ & $7.2^{\mathrm{a}}$ & $4.6^{\mathrm{a}}$ \\
\hline 20 & $12.0^{\mathrm{b}}$ & $98.8^{\mathrm{ab}}$ & $6.5^{\mathrm{ab}}$ & $4.4^{\mathrm{a}}$ \\
\hline 30 & $11.9^{\mathrm{bc}}$ & $98.8^{\mathrm{ab}}$ & $5.5^{\mathrm{bc}}$ & $4.3^{\mathrm{a}}$ \\
\hline 40 & $11.8^{\mathrm{bc}}$ & $98.8^{\mathrm{ab}}$ & $5.2^{\mathrm{bc}}$ & $4.1^{\mathrm{a}}$ \\
\hline 50 & $11.7^{\mathrm{bc}}$ & $97.7^{\mathrm{ab}}$ & $4.9^{\mathrm{bcd}}$ & $4.1^{\mathrm{a}}$ \\
\hline 60 & $11.6^{\mathrm{c}}$ & $97.7^{\mathrm{ab}}$ & $4.7^{\text {cd }}$ & $3.2^{\mathrm{b}}$ \\
\hline 70 & $11.3^{\mathrm{d}}$ & $95.2^{\mathrm{b}}$ & $4.5^{\mathrm{cd}}$ & $2.9^{\mathrm{b}}$ \\
\hline C.V\% & 1.5 & 2.3 & 17.0 & 8.3 \\
\hline
\end{tabular}

Means within columns followed by the same letters are not significantly different (Duncan's multiple range test).

$40{ }^{\circ} \mathrm{C}$ did not have any significant effect on germination percentages of adzuki bean seeds for all duration of exposure compared to untreated seeds. High germination percentages were achieved with exposure to $40{ }^{\circ} \mathrm{C}$ for 10 to 70 minutes. Exposure to heat at $40{ }^{\circ} \mathrm{C}$ for 10 minutes achieved percent germination that was significantly different to the percent germination achieved with 70 minutes exposure where percent germination was reduced to $95.5 \%$. It was observed that germination percentage achieved with 10 to 60 minutes of exposure, exceeded that of untreated seeds. As discussed before, the slight heating of seeds for short periods of exposure might have initiated germination.

Temperature at $40{ }^{\circ} \mathrm{C}$ also did not show any significant effects on root length for the different durations of exposure. However, root lengths were observed to exceed that in untreated seeds. Root length obtained with minimum exposure times of 10 and 20 minutes, were respectively 118 and $97 \%$ higher than root lengths obtained in the control, while with the maximum exposure times of 60 and 70 minutes, the lengths of root were respectively 42.4 and $36.4 \%$ higher than that in the control. As previously noted, a positive relationship exists between temperature increments and the duration of cell cycles in root development of beans. It could be concluded that heat treatment at a temperature at $40{ }^{\circ} \mathrm{C} \mathrm{did} \mathrm{not} \mathrm{have} \mathrm{any} \mathrm{adverse} \mathrm{effects} \mathrm{on} \mathrm{moisture} \mathrm{content,}$ germination, and root and shoot lengths of adzuki bean.

\subsubsection{Effect of constant heat at $50{ }^{\circ} \mathrm{C}$ on seed quality of adzuki been}

The effect of constant heat at a temperature of $50{ }^{\circ} \mathrm{C}$ on moisture content, germination percentage, and root and shoot lengths of adzuki bean are presented in Table 2 . When seeds were subjected to $50{ }^{\circ} \mathrm{C}$, moisture content was significantly $(\mathrm{p}<0.0001)$ affected at all durations of exposure. Seed moisture content decreased with increase in exposure time. No significant difference was observed in seed moisture content when seeds exposed for 10 to 40 minutes. When exposure time extended to 50 minutes, moisture content achieved is $11.7 \%$. Results showed that exposed seeds to heat at temperature of $50{ }^{\circ} \mathrm{C}$ resulted in moisture contents that did not exceed the required level for seed preservation.

The germination of adzuki bean seeds was not significantly affected by varying the duration of exposure at $50{ }^{\circ} \mathrm{C}$. Exposure to a temperature of $50{ }^{\circ} \mathrm{C}$ for 10,20 and 30 minutes resulted in improved germination percentages over that in untreated seeds. In addition, further exposure to 40 and 50 minutes did not show significant effects on seed germination, although germination was found to decrease as time of exposure increased. Significant differences were observed between percent germination achieved at 10 minutes compared to 50 minutes of exposure.

Table 2. Effect of constant heat at $50{ }^{\circ} \mathrm{C}$ on germination of adzuki beans

\begin{tabular}{|c|c|c|c|c|}
\hline \multirow{2}{*}{$\begin{array}{c}\text { Exposure time } \\
\text { (minutes) }\end{array}$} & \multicolumn{4}{|c|}{ Temperatures $\left(\mathbf{5 0}^{\circ} \mathrm{C}\right)$} \\
\hline & $\begin{array}{c}\text { Moisture content } \\
(\%)\end{array}$ & $\begin{array}{c}\text { Germination } \\
(\%)\end{array}$ & $\begin{array}{l}\text { Root length } \\
(\mathrm{cm})\end{array}$ & $\begin{array}{c}\text { Shoot length } \\
(\mathrm{cm})\end{array}$ \\
\hline Control & $13.6^{\mathrm{a}}$ & $96.7^{\mathrm{ab}}$ & $3.3^{\mathrm{b}}$ & $4.4^{\mathrm{ab}}$ \\
\hline 10 & $12.1^{\mathrm{b}}$ & $98.8^{\mathrm{a}}$ & $6.0^{\mathrm{a}}$ & $4.7^{\mathrm{a}}$ \\
\hline 20 & $12.1^{\mathrm{b}}$ & $97.8^{\mathrm{ab}}$ & $5.0^{\mathrm{ab}}$ & $4.3^{\mathrm{abc}}$ \\
\hline 30 & $11.9^{\mathrm{b}}$ & $97.7^{\mathrm{ab}}$ & $4.9^{\mathrm{ab}}$ & $3.9^{\mathrm{abc}}$ \\
\hline 40 & $11.9^{\mathrm{b}}$ & $96.6^{\mathrm{ab}}$ & $4.8^{\mathrm{ab}}$ & $3.4^{\mathrm{bc}}$ \\
\hline 50 & $11.7^{\mathrm{C}}$ & $93.3^{b}$ & $4.5^{\mathrm{ab}}$ & $3.2^{\mathrm{c}}$ \\
\hline C.V\% & 0.8 & 2.6 & 19.3 & 15.2 \\
\hline
\end{tabular}

Means within columns followed by the same letters are not significantly different (Duncan's multiple range test). 
In addition, exposure to a temperature of $50{ }^{\circ} \mathrm{C}$ did not show any significant effect on root and shoot lengths of adzuki bean seedlings. Root length in treated seeds exceeded that in the control for all durations of exposure. Significant difference was observed between root length obtained with 10 minutes of exposure compared to seeds in the control. It was observed that temperature affected root length positively. Shoot length in seeds exposed for 10 minutes exceeded shoot lengths obtained in the control. However, shoot length was significantly affected when seeds were exposed to $50{ }^{\circ} \mathrm{C}$ for 50 minutes.

It could be concluded that heat treatment at $50{ }^{\circ} \mathrm{C}$ did not affect germination of adzuki bean seeds. Bhalla, et al (2008) subjected cowpea seeds to heat treatment at $50{ }^{\circ} \mathrm{C}$ for 10 to 60 minutes, and observed that seed germination was slightly affected. In the present study, however germination was not affect by exposure of seeds to $50{ }^{\circ} \mathrm{C}$ for 10 to 50 minutes. This difference can be attributed to differences in crop sensitivity between cowpea and adzuki bean.

\section{2.3 Effect of constant heat at $60^{\circ} \mathrm{C}$ on seed quality of adzuki been}

The effect of constant heat at a temperature of $60{ }^{\circ} \mathrm{C}$ on moisture content, germination, and root and shoot lengths of adzuki bean seeds are presented in Table 3. Moisture content of adzuki bean for seeds treated with a temperature of $60{ }^{\circ} \mathrm{C}$ was significantly $(\mathrm{p}<0.0001)$ lower than that in untreated seeds for all durations of exposure. However, exposure to $60{ }^{\circ} \mathrm{C}$ temperature did not affect moisture content very much. No significant difference was observed between percentage of moisture content achieved between 10 and 30 minutes of exposure.

Table 3. Effect of constant heat at $60{ }^{\circ} \mathrm{C}$ on germination of adzuki bean

\begin{tabular}{|c|c|c|c|c|}
\hline \multirow{2}{*}{$\begin{array}{c}\text { Exposure time } \\
\text { (minutes) }\end{array}$} & \multicolumn{4}{|c|}{ Temperatures $\left(\mathbf{6 0}^{\circ} \mathbf{C}\right)$} \\
\cline { 2 - 5 } & $\begin{array}{c}\text { Moisture content } \\
(\boldsymbol{\%})\end{array}$ & $\begin{array}{c}\text { Germination } \\
(\boldsymbol{\%})\end{array}$ & $\begin{array}{c}\text { Root length } \\
(\mathbf{c m})\end{array}$ & $\begin{array}{c}\text { Shoot length } \\
(\mathbf{c m})\end{array}$ \\
\hline Control & $13.6^{\mathrm{a}}$ & $96.7^{\mathrm{a}}$ & $3.3^{\mathrm{b}}$ & $4.4^{\mathrm{ab}}$ \\
\hline 10 & $11.9^{\mathrm{b}}$ & $94.4^{\mathrm{a}}$ & $4.7^{\mathrm{a}}$ & $4.7^{\mathrm{a}}$ \\
\hline 20 & $11.8^{\mathrm{b}}$ & $90.0^{\mathrm{a}}$ & $4.3^{\mathrm{ab}}$ & $4.0^{\mathrm{ab}}$ \\
\hline 30 & $11.8^{\mathrm{b}}$ & $85.6^{\mathrm{a}}$ & $4.2^{\mathrm{ab}}$ & $3.8^{\mathrm{b}}$ \\
\hline C.V\% & 0.8 & 7.4 & 14.3 & 8.7 \\
\hline
\end{tabular}

Means within columns followed by the same letters are not significantly different (Duncan's multiple range test).

Exposure to heat at a temperature of $60{ }^{\circ} \mathrm{C}$ for 10,20 , and 30 minutes resulted in germination percentages that were not significantly different compared to untreated seeds. Percentage germination decreased with increase in exposure time. Exposure to heat at $60{ }^{\circ} \mathrm{C}$ for 10 minutes resulted in lower germination percentage than in the control. An exposure time of 20 minutes resulted in $90.0 \%$ seed germination. It was observed that exposure time of 30 minutes at a high temperature of $60{ }^{\circ} \mathrm{C}$ resulted in low percent germination compared to the other two durations.

Exposure to heat at a temperature of $60{ }^{\circ} \mathrm{C}$ resulted in root lengths exceeding that of controls for all durations of exposure. Results showed significant differences between root lengths with 10 minutes of exposure and that in the control. Exposure to $60{ }^{\circ} \mathrm{C}$ temperature did not show any significant effect on shoot length of adzuki bean. It could be concluded that the high temperature of $60{ }^{\circ} \mathrm{C}$ did not affect root and shoot lengths adversely, especially during short periods of exposure, which resulted in positive effects on root and shoot lengths of adzuki bean.

\subsubsection{Effect of constant heat at $70{ }^{\circ} \mathrm{C}$ on seed quality of adzuki been}

The influence of a constant temperature at $70{ }^{\circ} \mathrm{C}$ on moisture content, germination percentage, and root and shoot length of adzuki bean seeds are presented in Table 4 . The results showed that moisture content was significantly $(\mathrm{p}<0.0001)$ affected at a temperature of $70{ }^{\circ} \mathrm{C}$ for all durations of exposure. Seed moisture content decreased with increase in exposure time. However, levels of seed moisture content achieved with $70{ }^{\circ} \mathrm{C}$ did not exceed the level of moisture content of seed storage. This result was also confirmed in the previous findings of the effect of solar heater boxes.

Table 4. Effect of constant heat at $70^{\circ} \mathrm{C}$ on germination of adzuki bean

\begin{tabular}{|c|c|c|c|c|}
\hline \multirow{2}{*}{$\begin{array}{c}\text { Exposure time } \\
\text { (minutes) }\end{array}$} & \multicolumn{4}{|c|}{ Temperatures $\left(\mathbf{7 0}^{\circ} \mathrm{C}\right)$} \\
\hline & $\begin{array}{c}\text { Moisture content } \\
(\%)\end{array}$ & $\begin{array}{c}\text { Germination } \\
(\%)\end{array}$ & $\begin{array}{l}\text { Root length } \\
\text { (cm) }\end{array}$ & $\begin{array}{c}\text { Shoot eights } \\
(\mathrm{cm})\end{array}$ \\
\hline Control & $13.6^{\mathrm{a}}$ & $96.7^{\mathrm{a}}$ & $3.3^{\mathrm{ab}}$ & $4.4^{\mathrm{a}}$ \\
\hline 20 & $11.7^{\mathrm{c}}$ & $71.1^{\mathrm{bc}}$ & $3.3^{\mathrm{ab}}$ & $3.9^{\mathrm{a}}$ \\
\hline 30 & $11.7^{\mathrm{c}}$ & $60.0^{\mathrm{c}}$ & $2.8^{\mathrm{b}}$ & $3.7^{\mathrm{a}}$ \\
\hline C.V\% & 0.6 & 12.1 & 16.8 & 12.1 \\
\hline
\end{tabular}


The results also showed that, germination percentage decreased with increase in exposure time, and was significantly affected by exposure to heat at $70{ }^{\circ} \mathrm{C}$. Exposure to temperatures of $70{ }^{\circ} \mathrm{C}$ for 10 minutes decreased germination to $81.1 \%$, which was not significantly different with the germination percentage in the control; however, exposure for 20 and 30 minutes decreased germination to significant levels of $71.1 \%$ and $60.0 \%$ respectively compared to the germination in the untreated control.

Root lengths of adzuki bean were not affected by exposure to $70{ }^{\circ} \mathrm{C}$. Root lengths obtained with the minimum exposure times of 10 minutes exceeded root lengths obtained in the control, while with exposure times of 20 minutes; the length of roots was similar to that in the control. No significant effects were observed on shoot length of adzuki bean when seeds were exposed to a temperature of $70{ }^{\circ} \mathrm{C}$ for all durations.It was observed that exposure to $70{ }^{\circ} \mathrm{C}$ for more than 10 minutes was not suitable as seed treatment as they caused significant detrimental effects on seed moisture content and germination of adzuki bean. It was observed that, a temperature of $50{ }^{\circ} \mathrm{C}$ did not affect germination of adzuki bean seeds. Murdock and Shade (1991) reported that exposure times and temperatures needed to disinfest cowpeas had no significant impact on seed germination percentages. They exposed seeds for one hour at a temperature of $57.3{ }^{\circ} \mathrm{C}$ (generated in an oven) and observed no significant adverse effects on germination of cowpea seeds. Lale and Ajayi (2001) also indicated that exposure to solar heat in metal tins of up to $57{ }^{\circ} \mathrm{C}$ for 7 hours had no adverse affects on the germinability of bambara groundnuts. In the present study, the adzuki bean seeds were exposed for a maximum duration of 2 hours with solar heater boxes, and for 70 minutes in an oven, and these did not affect their germinability adversely.

Hartman et al (2002) mentioned that above an optimum level of temperatures, germination may remain relatively constant, at least over the middle part of the temperature range, if sufficient time is allowed for germination to occur. In the present study the temperatures with particular exposure times initiated the germination of seeds. It was observed that exposure to heat at 40 and $50{ }^{\circ} \mathrm{C}$ elongate the root lengths of adzuki bean more than that in untreated seeds. As has been discussed before, this could be due to the positive effect of temperature on root length, and to the fact that slight heating for short periods of exposure initiate germination of seeds. The results also showed that at temperatures of 40 and $50{ }^{\circ} \mathrm{C}$, germination percentages exceeded that in the control. Similar effects of temperature on germination were reported by Chauhan and Ghaffar (2002) who observed that germination of pigeon pea was $90 \%$ prior to treatment, but after heat treatment at $65{ }^{\circ} \mathrm{C}$ the germination was increased to $92 \%$.

The effects on germination of adzuki bean seeds receiving the treatment are additional considerations that encourage the acceptance of solar heater boxes by low resource farmers. The results of the present study showed that cardboard and plywood solar heater box treatments with variation in temperature do not have an enormous influence on germination characters of adzuki bean seeds, especially with less than one hour of exposure. In both solar heater boxes tested, the seed moisture content did not exceed the required level of moisture content for seed preservation. However, the use of cardboard solar heater boxes is preferable as it did not reduce seed moisture content to less than $10 \%$. The results obtained in the constant heat experiments on seed quality of adzuki bean support the results obtained with cardboard and plywood solar heater boxes. Temperatures of $40{ }^{\circ} \mathrm{C}$ with 70 minutes exposure and $50{ }^{\circ} \mathrm{C}$ with 50 minutes exposure are recommended for effective seed treatment with minimum effect on seed quality.

\section{Acknowledgment}

Many thankful to the University Putra Malaysia (UPM) for sponsoring the research through the Faculty of Agriculture, Department of Plant Protection.

\section{References}

[1]. Bhalla, S., Gupta, K., Lal, B., Kapur, M. L., and Khetarpal, R. K. (2008). Efficacy of various non-chemical methods against pulse beetle, Callosobruchus maculatus (F.).( ENDURE International Conference 2008 Diversifying crop protection, 12-15 October 2008 La Grande-Motte, France - Oral presentations)

[2]. Burg, H.B. (2004). Small-scal seed production; with variety improvemnet of cerials and pulses. In N. Edwin (Ed.), (1 $1^{\text {st }}$ ed.), pp. 835 . Wageningen-Netherland: Digigrafi.

[3]. Chauhan, Y. S., and Ghaffar, M. A. (2002). Solar heating of seeds-a low cost method to control bruchid (Callosobruchus spp.) attack during storage of pigeonpea. Journal of Stored Products Research, 38(1), 87-91.

[4]. Creber, H. M. C., Davies, M. S., and Francis, D. (1993). Effects of temperature on cell division in root meristems of natural populations of Dactylis glomerata of contrasting latitudinal origins. Environmental and Experimental Botany, 33(3), 433-442

[5]. Fery, R. L. (2002). New opportunities in Vigna. In,Janick,J., and Whipkey,A.(eds).Trends in new crops and new uses. Alexandria: ASHS Press.

[6]. Gonzales, M. D., Archuleta, E., Farmer, A., Gajendran, K., Grant, D., Shoemaker, R., Beavis, W. D., and Waugh, M. E. (2005). The Legume Information System (LIS): an integrated information resource for comparative legume biology. Nucleic Acids Research, 33

[7]. Graham, P. H., and Vance, C. P. (2003). Legumes: importance and constraints to greater use. Plant Physiology, 131 (3), 872.

[8]. Hartmann, H.T., Kester, D.E., Davies, F.T., and Geneve, R.L. (Eds.). (2002). Plant Propagation: Principles and Practices (7 ${ }^{\text {th }}$ ed.). New Jersey: Pearson Education,Inc. 
[9]. Hill, D. S. (1975). Agricultural Insect Pests of the Tropics and their Control. London:Cambridge.

[10]. ISTA (2007). ISTA Handbook on Moisture Determination (eds H Nijenstein, J. Nydam, R. Don and C. McGill). International Seed Testing Association, Bassersdorf, Switzerland.

[11]. Khanna, P. (2008). Cell and Molecular Biology. New Dellhi-India: International Publishing House.Pvt.Ltd.

[12]. Lale, N. E. S., and Ajayi, F. A. (2001). Suppression of development of Callosobruchus maculatus (F.)(Col.: Bruchidae) in bambara groundnut seeds exposed to solar heat in the Nigerian savanna. Anzeiger für Schädlingskunde, 74(5), 133-137.

[13]. Mbaiguinam, M., Maoura, N., Bianpambe, A., Bono, G., and Alladoumbaye. E. (2006). Effects of six common plant seed oils on survival, eggs laying, and development of cow pea weevil, Callosobruchus maculatus (F. (Coleoptera: Bruchidae). Journal of Biological Science, 6(2), 420-425.

[14]. Mekasha, C.W. (2004). Utilization of Solar Heat for The Control of Cowpea Seed Beetle, Callosobruchus maculatus (F.) (Coleoptera: Bruchidae)Univercity Putra Malaysia.

[15]. Mekasha.C., Dzolkifli, O., Yusuf, S., Rita, M., and Noorma, O. (2006). Development of efficient solar heaters for storage insect pest management. African Crop Science Journal, 14(3), 253-261.

[16]. Murdock, L. L., and Shade, R. E. (1991). Eradication of cowpea weevil (Coleoptera: Bruchidae) in cowpeas by solar heating. American Entomologist, 37(4), 228-231.

[17]. Ntoukam, G., Kitch, L. W., Shade, R. E., and Murdock, L. L. (1997). A novel method for conserving cowpea germplasm and breeding stocks using solar disinfestation. Journal of Stored Products Research, 33(2), 175-179.

[18]. Russelle, M.(2001).Alfalfa. American journal of Science.89:252-259.Tardieu, F., and Granier, C. (2000). Quantitative analysis of cell division in leaves:methods, developmental patterns and effects of environmental conditions.In D. Inze (Ed.), The plant cell cycle. Kluwar Academic Publisher. Dordrecht, Netherlands: Vance, C.P., Graham, P.H., and Allan,D.L.(2000). Biological Nitrogen Fixation.

[19]. Phosphorous:a critical future need. In Pedrosa, F.O.,Hugeria,M.,Yates,M.G.,a Newton,W.E.(eds).Nitrogen Fixation:From Molecules to Crop Productivity. Kluwer Academic Publishers, Dordrecht, The Netherlands, pp 506-514.

[20]. Welch, R.S., 1999. Importance of seed mineral nutrient reserves in crop growth and development. In Z. Rangel (Ed.), Mineral nutrition of crops:Fundimental mechanisms and implications (pp. 399). The Haworth press, Inc Binghamton.

[21]. Yousif, A. M., Deeth, H. C., Caffin, N. A., and Lisle, A. T. (2002). Effect of Storage Time and Conditions on the Hardness and Cooking Quality of Adzuki (Vigna angularis). Lebensmittel-Wissenschaft und-Technologie, 35(4), 338-343. 